\title{
CELLULOSIC MATERIALS AS POLYMER ELECTROLYTE MEMBRANE IN FUEL CELL APPLICATION
}

\author{
Cynthia L. Radiman *, A. Sarinastiti ** \\ Inorganic and Physical Chemistry Division, Institut Teknologi Bandung \\ Jalan Ganesha 10, Bandung 40132, Indonesia \\ *cynthia@chem.itb.ac.id, ${ }^{* *}$ asrisarinastiti@gmail.com
}

Diterima : 26 Nopember 2012, Revisi akhir : 27 Desember 2012

\section{TURUNAN SELULOSA SEBAGAI MEMBRAN POLIMER ELEKTROLIT UNTUK APLIKASI SEL BAHAN BAKAR}

\begin{abstract}
ABSTRAK
Sel bahan bakar membran polimer eletrolit (PEMFC) dan sel bahan bakar metanol (DMFC) merupakan sumber energi masa depan yang dapat mengatasi krisis energi minyak bumi. Tujuan penelitian ini adalah untuk menggunakan bahan alam Indonesia yang dimodifikasi secara kimiawi supaya sifat-sifatnya dapat ditingkatkan untuk memenuhi persyaratan sebagai membran elektrolit. Dalam penelitian ini air kelapa telah digunakan sebagai bahan dasar dan selanjutnya difermentasi oleh Acetobacter xylinum. Selulosa bakterial yang dihasilkan difosforilasi dengan bantuan gelombang mikro. Membran tersebut direndam selama waktu yang bervariasi ( 0-8 jam) dalam campuran N,Ndimetilasetamida (DMF), asam fosfat dan urea sebelum diiradiasi dengan gelombang mikro selama 60 detik. Karakterisasi membran dilakukan dengan berbagai metoda, antara lain analisis gugus fungsi dengan FTIR, konduktivitas proton, kapasitas penukar ion, indeks penggembungan, analisis morfologi dengan SEM dan analisis kadar fosfor dengan SEM-EDS. Dari data yang diperoleh disimpulkan bahwa selulosa bakterial yang difosforilasi dengan proses perendaman selama 4 jam dapat digunakan sebagai alternatif untuk membran elektrolit dalam aplikasi sel bahan bakar.
\end{abstract}

Kata kunci: sel bahan bakar, selulosa bakterial, selulosa bakterial terfosforilasi

\begin{abstract}
Polymer Electrolyte Membrane Fuel Cells (PEMFC) and Direct Methanol Fuel Cell (DMFC) are considered as future power sources in overcoming the fossil-based energy crisis. The objective of this work is to explore one of the natural resources of Indonesia and to improve its properties by chemical modification in order to get the required characteristics as electrolyte membrane. In this work coconut water was used as the basic material. It was fermented by Acetobacter xylinum and the resulting bacterial cellulose was then phosphorylated using a microwave-assisted reaction. Those membranes have been immersed for a varied time ranging between 0 and 8 hours $(0-8 \mathrm{~h})$ in a mixture of N,Ndimethylformamide (DMF), phosphoric acid and urea prior to irradiation by microwave for $60 \mathrm{~s}$. Those membranes were characterized by several methods, such as functional group analysis by FTIR, proton conductivity, ion exchange capacity, swelling index, morphology analysis by SEM and phosphorus content analysis by SEM-EDS. From the experimental data, it can be concluded that a phosphorylated bacterial cellulose prepared by a $4 \mathrm{~h}$-immersion could be used as an alternative electrolyte membrane for fuel cell applications.
\end{abstract}

Keywords: fuel cell, bacterial cellulose, phosphorylated bacterial cellulose 


\section{INTRODUCTION}

Limited fossil-based energy resources and increasing energy demand result in global energy crisis. Fuel cells are considered as potential resources in overcoming this problem. Polymer Electrolyte Membrane Fuel Cells (PEMFCs) and Direct Methanol Fuel Cells (DMFCs) have more advantages compared to other types of fuel cells. These devices are based on electrochemical reactions in which hydrogen or methanol can be used as fuel (Kamarudin et. al., 2009). So, these reactions belong to green chemistry as they use environmentally-friendly reactions. In order to produce electricity, fuel cells should have three main components which are anode, cathode and electrolyte membrane (Stambouli, 2011). The membrane should fulfill some requirements such as high proton conductivity, low permeability to fuel, high mechanical properties and high thermal stability.

At present $\mathrm{Nafion}^{\circledR}$ is used as commercial membrane for PEMFC and DMFC applications. However, this membrane is expensive and has a permeability towards methanol (Neburchilov et. al., 2007). If methanol as fuel can easily pass through the membrane from anode to cathode, the efficiency of the fuel cell will decrease significantly. Beside that, the presence of methanol at the cathode will affect the catalytic layer on the cathode, oxydize the methanol and decrease the electrode potential (Silva et. al., 2005). Besides that, Nafion ${ }^{\circledR}$ is a fluoropolymer, so the degradation product could harm the environtment. Therefore, efforts should be done to find new materials for electrolyte membranes.

In this work we tried to use cellulosic material as the base material for preparing an alternative for electrolyte membrane. This cellulosic membrane, called bacterial cellulose, is prepared by fermentation of coconut water using Acetobacter xylinum. This kind of cellulose is free of lignin and has a very different fibrilar structure compared to plant cellulose. Our previous work shows that it has a very high mechanical strength due to its regular chain structure pattern (Radiman and Yuliani, 2008). The resulting gels can be pressed to make flat films and then modified chemically to get higher conductivity. Therefore, the objectives of this work is to explore the richess of our natural resources and to improve their properties by chemical modification such as phosphorylation. The effects of immersion in the reactants prior to phosphorylation and the reaction method are studied in this work. The resulting membranes were then characterized by several methods such as proton conductivity, Ion Exchange Capacity (IEC), degree of swelling and morphology.

\section{EXPERIMENTAL}

\section{Materials}

Coconut water and sugar were obtained from the local traditional market, while Acetobacter xylinum was taken from the local industry. Other chemicals such as ammonium sulfate, acetic acid, sodium hydroxide, oxalic acid, hydrochloric acid, sulfuric acid, phosphoric acid 85\%, urea, N,Ndimethylformamide (DMF) were obtained from E. Merck and used without further purification.

\section{Preparation of Bacterial Cellulose}

Bacterial cellulose was prepared using the same procedure as our previous experiment (Radiman and Yuliani, 2008). Fermentation was done during six days at room temperature and the resulted gels were put in the boiling water for 15 minutes. Then they were soaked in $1 \%(\mathrm{w} / \mathrm{w})$ aqueous solution of sodium hydroxide for 24 hours, followed by $1 \%(\mathrm{w} / \mathrm{w})$ aqueous solution of acetic acid for another 24 hours. Finally, they were washed with water until the $\mathrm{pH}$ was neutral. The bacterial cellulosic gels were finally pressed using an applied pressure of 147 bars for three minutes and dried at room temperature.

\section{Phosphorylation of Bacterial Cellulose Membranes}

An amount of $17.35 \mathrm{mmol}$ of phosphoric acid was mixed with $50 \mathrm{~g}$ of urea and $100 \mathrm{~mL}$ of DMF. Dried bacterial cellulose was immersed in that mixture during a certain time ranging from 0 to 8 hours before the phosphorylation. A microwave oven with a power of 560 Watts was used for the phosphorylation. Two methods were used for this experiment; the first one used a continuous reaction for 60 seconds, while the second one used a discontinuous reaction of six successive reactions of 10 seconds each. The resulting phosphorylated cellulose was washed several times with deionized water to remove all the residual reactants. 


\section{Characterization of Phosphorylated Cellulose Membranes}

Functional groups of bacterial cellulose and the phosphorylated ones were analyzed by Alpha FTIR spectrophotometer from Bruker. One mg of membrane powder was mixed with $\mathrm{KBr}$ and mechanically pressed to become $\mathrm{KBr}$ pellets. The sample was then put into the sample holder and scanned between 4000 and $500 \mathrm{~cm}^{-1}$.

Proton conductivity of membranes were calculated by impedance measurement using Agilent E4980A LCR meter. Prior to measurement, membranes were immersed in 40 $\mathrm{mL}$ of $0.01 \mathrm{M} \mathrm{H}_{2} \mathrm{SO}_{4}$ solution for 24 hours. Then the membranes were washed with deionized water repeatedly to remove the residual acids until the $\mathrm{pH}$ of the filtrate was neutral. The membrane was put between two electrodes and the measurement was done at $80^{\circ} \mathrm{C}$ with $\mathrm{AC}$ current in the range of $2 \mathrm{~Hz}-2 \mathrm{MHz}$ with an amplitudee of $1 \mathrm{~V}$. Nafion $117^{\circledR}$ was used as reference. Proton conductivity was calculated using Equation 1.

$$
\sigma=\frac{1}{\mathrm{RA}}
$$

$\sigma=$ proton conductivity

$1=$ membrane thickness

$\mathrm{A}=$ membrane surface area

$\mathrm{R}=$ ionic resistance

A sample of bacterial cellulose membrane was weighed and soaked in $40 \mathrm{~mL}$ of $0.1 \mathrm{M}$ $\mathrm{HCl}$ solution at room temperature. Then it was neutralized and soaked again in $50 \mathrm{~mL}$ of $0.01 \mathrm{M}$ $\mathrm{NaOH}$ solution overnight at room temperature. A volume of $10 \mathrm{~mL}$ was taken from this solution and titrated with $0.01 \mathrm{~N} \mathrm{H}_{2} \mathrm{SO}_{4}$ solution (Smitha et. al., 2005). The IEC was calculated using Equation 2.

$$
\mathrm{IEC}=\frac{(\mathrm{Vb}-\mathrm{Vs})[\mathrm{Acid}] . f \mathrm{p}}{\mathrm{m}}
$$

Where:

$$
\begin{aligned}
\mathrm{V}_{\mathrm{b}}= & \text { amount of } \mathrm{H}_{2} \mathrm{SO}_{4} \text { solution for } \\
& \text { neutralizing the blank solution }(\mathrm{mL}) \\
\mathrm{V}_{\mathrm{s}}= & \text { amount of } \mathrm{H}_{2} \mathrm{SO}_{4} \text { solution for } \\
& \text { neutralizing the solution containing the } \\
& \text { membrane }(\mathrm{mL}) \\
\text { [Acid] }= & \text { concentration of sulfuric acid }(\mathrm{N})
\end{aligned}
$$

$f_{\mathrm{p}}=$ dilution factor

$\stackrel{\mathrm{p}}{\mathrm{m}}=$ mass of sample $(\mathrm{g})$

For swelling index measurement, samples were weighed at room temperature and then soaked in deionized water (Lee and Shin, 1991). Membranes were then dried using tissue paper and weighed again. The procedure was repeated until the membrane reached a constant weight.

Swelling index $(S I) S I)$ was calculated using Equation 3.

$$
\% \mathrm{SI}=\frac{\mathrm{m}-\mathrm{m}_{\mathrm{o}}}{\mathrm{m}_{\mathrm{o}}} \times 100 \%
$$

\section{Where}

$\mathrm{m}=$ mass of dry membrane $(\mathrm{g})$

$\mathrm{m}_{\mathrm{o}}=$ mass of wet membrane $(\mathrm{g})$

Membrane morphology was observed by using SEM and Energy Dispersive X-Ray Spectroscopy (EDS) of JEOL-JSM-6510LV.

\section{RESULTS AND DISCUSSION}

\section{Functional Groups Analysis of Phosphorylated Bacterial Cellulose}

Figure 1(a) shows the characteristic functional groups of the original nata-de-coco. The broad peak at $3350 \mathrm{~cm}^{-1}$ proves the presence of $-\mathrm{OH}$ groups, while glycosidic linkages -C-O-C appears at $1161 \mathrm{~cm}^{-1}$ and $-\mathrm{CO}$ for primary alcohol at 1034 $\mathrm{cm}^{-1}$. The peak at $1337 \mathrm{~cm}^{-1}$ is attributed to $\mathrm{C}-\mathrm{H}$ bending vibration. A new peak weakly appeared at $1278 \mathrm{~cm}^{-1}$ which is attributed to the stretching vibration of $\mathrm{P}=\mathrm{O}$ groups. Urea was used in the phosphorylation of nata-de-coco. According to Oshima et al., the urea was indispensable for the reaction since urea plays a role to activate the phosphate groups and form a phosphate ester (Oshima et. al,.2008). The later acts as a better leaving group than hydroxyl groups. Using microwave radiation, the phosphorylation took place in $150 \mathrm{~s}$, a reaction time much faster than a conventional chemical reaction (Lidstörm et. al., 2001). Regarding the reactivity of hydroxyl groups, the primary alcohols have higher reactivity than the secondary ones due to smaller steric hindrance. As proposed by Wan et al., the phosphorylation reaction took place firstly at the C-6 glucose unit (Wan et. al., 2003). 
Effects of Immersion Time and Reaction Method on The Proton Conductivity of Phosphorylated Bacterial Cellulose Membranes

Figure 1 shows that immersion time and method of phosphorylation affect the proton conductivity of phosphorylated bacterial cellulose membranes. Longer immersion time in the discontinuous reaction increases the proton conductivity up to 4 hours but then decreases. This fact suggests that the substitution of hydroxyl groups by phosphate groups needs time to occur, because the orientation of cellulose chains in bacterial cellulose is very regular. In order to have a chemical modification, the cellulosic chains have to be swollen first. The swelling period will enlarge the gap among polymer chains and hence, the phosphoric acid can penetrate more easily. In the continuous method, the effect of immersion time seems to be unsignificant. Moreover, the time for swelling is shorter than in the discontinuous method, and therefore, the increase of the conductivity is less pronounced. The decrease of conductivity after 4 hours of immersion in the discontinuous reaction suggests that the phosphoric groups can create crosslinks with the hydroxyl groups of other cellulose chains.
The proton conductivity of Nafion ${ }^{\circledR}$ and the phosphorylated bacterial cellulose at its optimum condition is $7.63 \times 10^{-1} \mathrm{~S}_{\mathrm{cm}} \mathrm{cm}^{-1}$ and $1.17 \times 10^{-1} \mathrm{~S} . c m^{-1}$, respectively. This data shows that the bacterial cellulose can be considered as an alternative material for polymer electrolyte membrane.

\section{Effects of Immersion Time and Reaction Method on The Ion Exchange Capacity (IEC) of Phosphorylated Bacterial Cellulose Membranes}

Ion Exchange Capacity (IEC) of electrolyte membrane describes the amount of ionic groups in the polymer matrix. Protons can be transported through the membrane by hopping mechanism. Figure 2 shows that in the discontinuous reaction the IEC is increasing when the membrane was immersed up to 4 hours. If the immersion time is longer than 4 hours, the IEC will go down again. In the contrary, the continuous reaction results in higher IEC if the immersion time is longer than 4 hours. This data shows that the distribution of ionic groups in the resulting membranes are not similar. The hydrophylic domains in the continuous reaction is more homogeneous than in the discontinuous method. According to Peckham et al., a material can function as

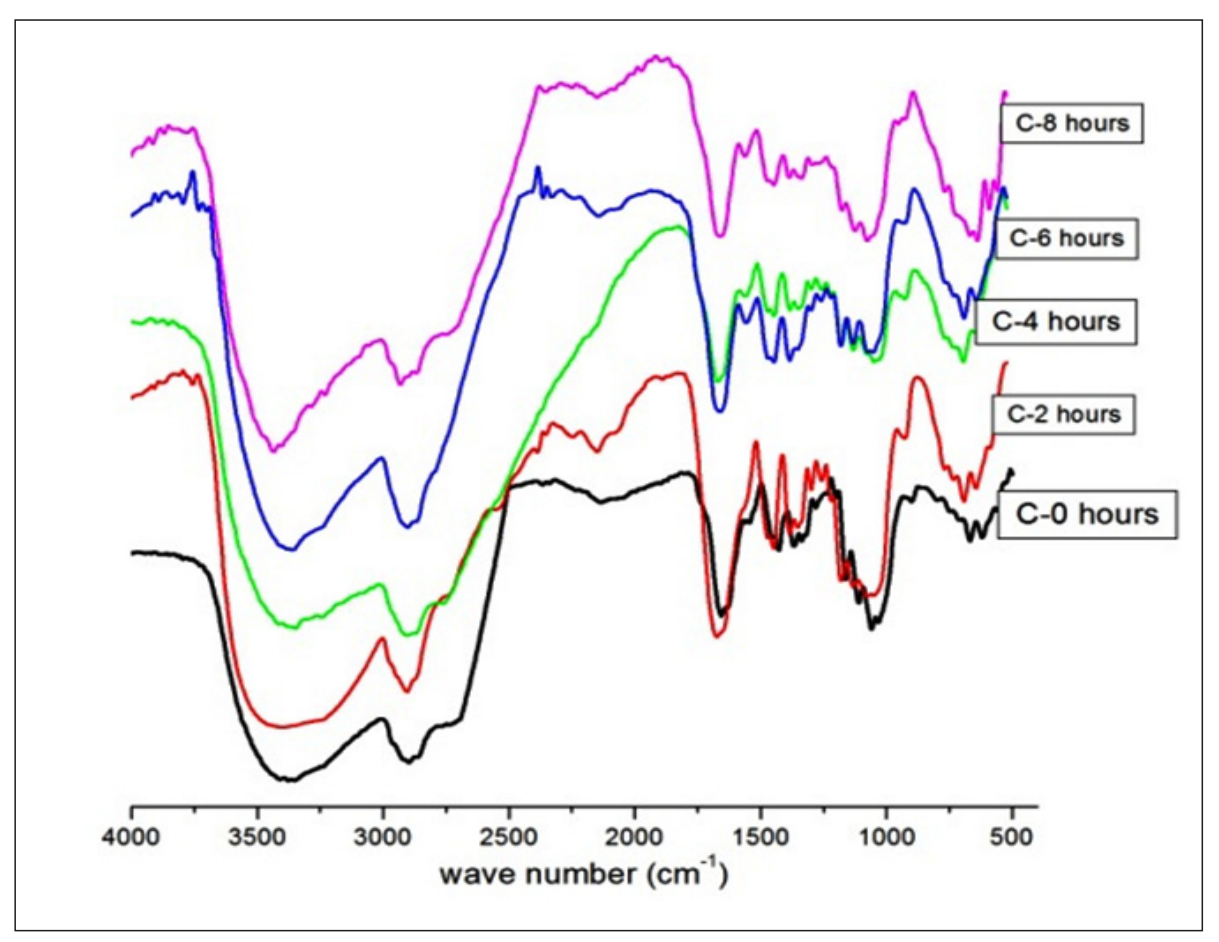

Figure 1. FTIR Spectra of Phosphorylated Bacterial Cellulose 


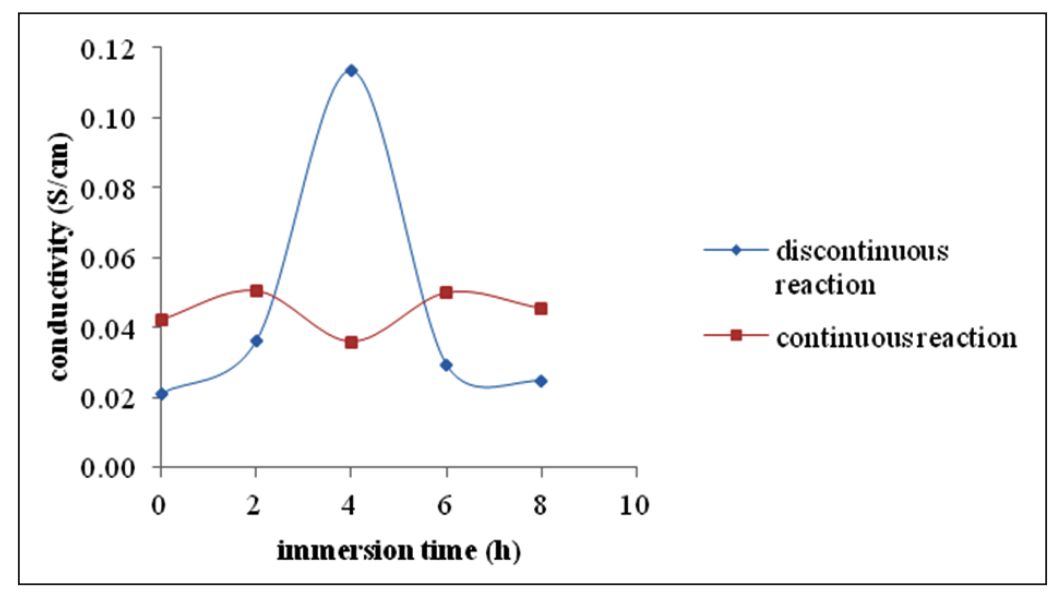

Figure 1. Proton Conductivity of Phosphorylated Bacterial Cellulose Membranes

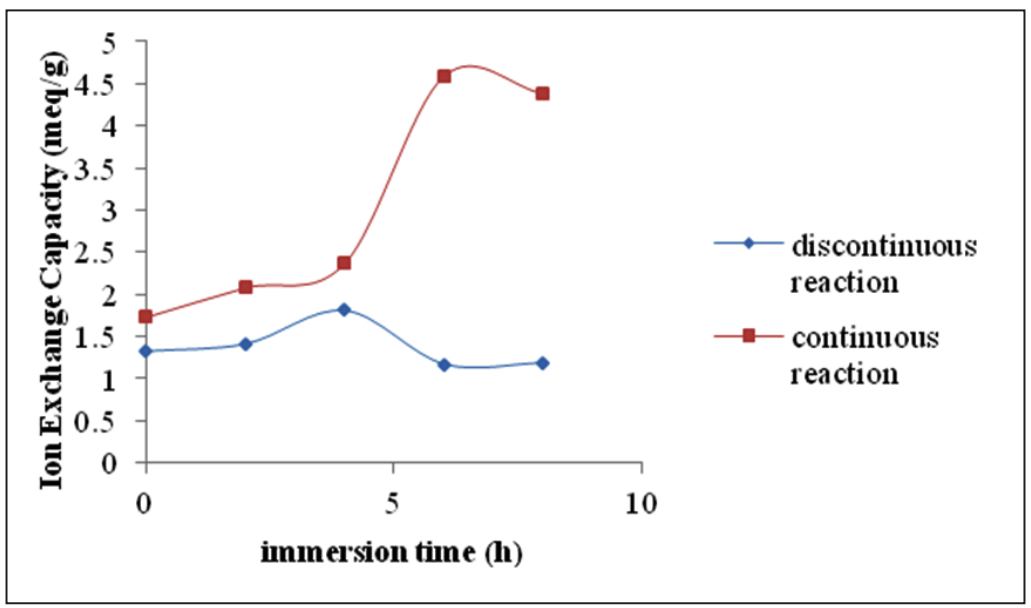

Figure 2. Ion Exchange Capacity of Phosphorylated Bacterial Cellulose Membranes

electrolyte membrane if it has both hydrophilic and hydrophobic domains which enable the proton transport through a cluster-channel network (Peckham et. al., 2007).

\section{Effects of Immersion Time and Reaction \\ Method on The Swelling Index of Phosphorylated Bacterial Cellulose Membranes}

Figure 3 shows the swelling index of various membranes prepared by phosphorylation of bacterial celllose. In fuel cell applications, membranes should have a moderate degree of swelling in order to get a high ion mobility (George et. al., 1999). A low degree of swelling makes ion mobility difficult, but on the other hand, a high degree of swelling softens the membrane and then decreases its mechanical properties. From Figure 3 it can be seen that the discontinuous reaction produces membranes with higher swelling index than the continuous one. The discontinuous reaction allows the celulose chains to swell so that the reagent can penetrate between those chains. The tendency of this swelling behaviour plays an important role for the proton conductivity, because phosphate groups can substitute the hydroxyl groups of the swollen cellulose. Consequently, the conductivity of the membranes will increase. Considering the role of phosphoric acid as crosslinking agent for nata-de-coco and other polymers (Kalyani et. al., 2006), it can be suggested that at high concentration of phosphoric acid, the formation of crosslinks among polymer chains has taken place. Based on the parameters discussed above, it can be concluded that the discontinuous reaction produces membranes with good proton conductivity. The $4 \mathrm{~h}$-immersion time was chosen as the optimum condition. 


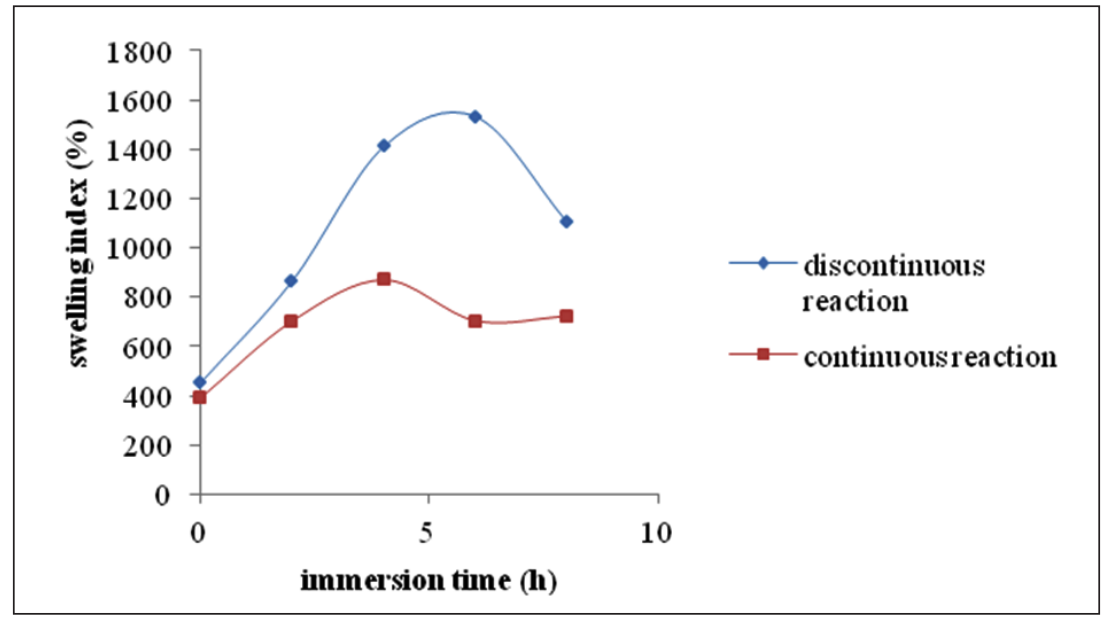

Figure 3. Swelling Index of Phosphorylated Bacterial Cellulose Membranes

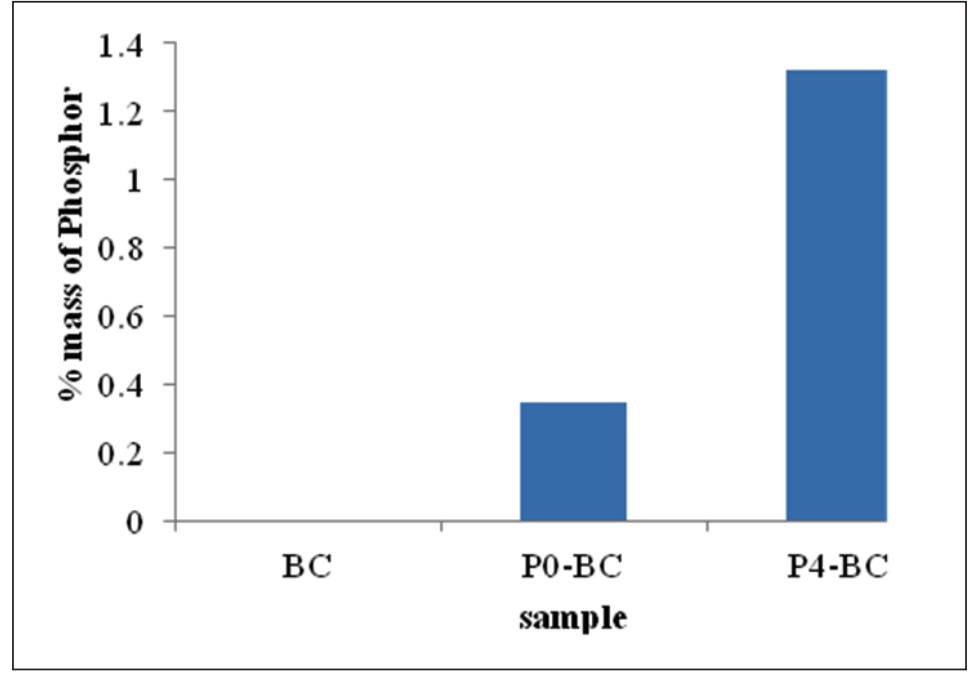

Figure 4. Content of Phosphor in Various Phosphorylated Bacterial Cellulose Membranes

\section{Phosphor Content of Various Bacterial Cellulose Membranes}

Some of the membranes were analysed by SEM-EDAX to determine the content of phosphor on the surface of the membranes. The abbreviation $\mathrm{BC}$ stands for the original bacterial cellulose, while $\mathrm{P} 0-\mathrm{BC}$ and $\mathrm{P} 4-\mathrm{BC}$ for phosphorylated bacterial cellulose with immersion time of $0 \mathrm{~h}$ and $4 \mathrm{~h}$, respectively. This data confirms that immersion can make the penetration of phosphoric acid more effective. The P4-BC sample contains about 4 times more phosphor than the $\mathrm{P} 0-\mathrm{BC}$. This condition results in higher proton transfer and higher proton conductivity as well.

\section{Morphology of Various Bacterial Cellulose Membranes}

Figure 5 shows the morphology of membrane surface observed by SEM using the same membranes described in the previous section. It can be seen that after the phosphorylation, the membranes still maintain their profiles. Figure 5(a) shows that the surface of the original bacterial cellulose is dense and the fibers are entangled to each other. On the other hand, one can see clearly that the phosphorylated bacterial cellulose immersed during 4 hours has some deposits on the surface. From this observation, it can be concluded that the phosphorylation is more effective when the membrane is immersed in the reagent for an optimum time. 


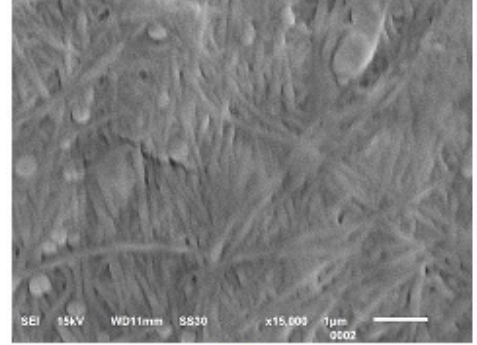

(a)

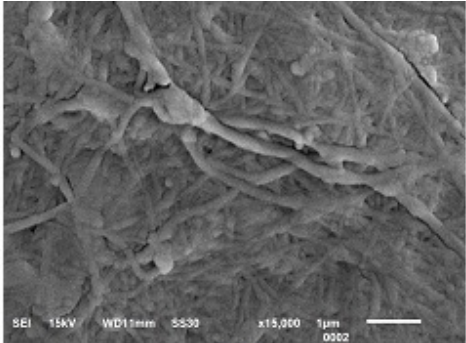

(b)

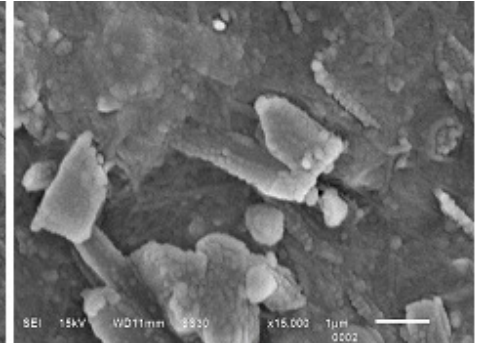

(c)

Figure 5. Morphology of Membrane Surface of (a) BC, (b) P0-BC and (c) P4-BC

\section{CONCLUSIONS}

From this work it can be concluded that environmentally-friendly and cheap polymer electrolyte membrane can be prepared from coconut water by microwave-assisted phosphorylation. By varying the immersion time and phosphorylation method, an optimum condition has been found. So, bacterial cellulose immersed during 4 hours prior to phosphorylation and reacted with a discontinuous method produces optimum characteristics as electrolyte membranes. The proton conductivity of this cellulosic material is in the same order as Nafion $117^{\circledR}$.

\section{REFERENCES}

George, S., Knőrgen, M., Thomas, S., 1999. Effect of nature and extent of crosslinking on swelling and mechanical behavior of styrene-butadiene rubber membranes. $J$ Memb Sci, 163, 1-17.

Kalyani, S., Smitha, B., Sridhar, S., Krishnaiah, A.. 2006, Separation of ethanol-water mixtures by pervaporation using sodium alginate/poly(vinyl pyrrolidone) blend membrane crosslinked with phosphoric acid. Ind Eng Chem Res, 45, 9088-9095.

Kamarudin, S. K., Achmad, F., Daud, W. R. W., 2009. Overview on the application of direct methanol fuel cell (DMFC) for portable electronic device. Intl J Hydr Energy 34, 6902-6916.

Lee, Y. M., Shin, E. M., 1991. Pervaporation Separation of Water-Ethanol Through Modified Chitosan Membranes. IV. Phosphorylated Chitosan Membranes. $J$ Memb Sci., 64, 145-152.

Lidstőrm, P., Tierney, J., Wathey, B., Westman, J., 2001. Microwave assisted organic synthesis - a review. Tetrahedron, 57, 9225-9283.
Neburchilov, V., Martin, J., Wang, H., Zhang, J., 2007. A review for polymer electrolyte membranes for direct methanol fuel cells. $J$ Power Source, 169, 221-238.

Oshima, T., Kondo, K., Ohto, K., Inoue, K., Baba, Y., 2008. Preparation of phosphorylated bacterial cellulose as an adsorbent for metal ions. Reactive \& Funct Polym, 68, 376-83.

Peckham, T. J., Schmeisser, J., Rodgers, M., Holdcroft, S., 2007. Main-chain, statistically sulfonated proton exchange membranes: the relationships of acid concentration and proton mobility to water content and their effect upon proton conductivity. $J$ Mater Chem 17, 3255-3268.

Radiman, C., Yuliani, G., 2008. Coconut water as a potential resource for cellulose acetate membrane preparation. Polym Intl, 57,502508.

Silva, V. S., Schirmer, J., Reissner, R., Ruffmann, B., Silva, H., Mendes, A., 2005. Proton electrolyte membrane properties and direct methanol fuel cell performance II. Fuel cell performance and membrane properties effects. J Power Source 20, 140, 41-49.

Smitha, B., Sridhar, S., Khan, A. A., 2005. Synthesis and characterization of poly(vinyl alcohol)-based membranes for direct methanol fuel cell. J Appl Polym Sci, 95, 1154-1163.

Stambouli, A. B., 2011. Fuel cells: The expectations for an environmental-friendly and sustainable source of energy. Renewable \& Sustainable Energy Rev, 15,4507-4520.

Wan, Y., Creber, K. A. M., Peppley, B., Bui, V. T., 2003. Synthesis, characterization and ionic conductive properties of phosphorylated chitosan membranes. Macromol Chem Phys, 204, 850-858. 